\title{
AI-Si-Cu 合金の衝撃強さにおよぼす
}

\section{マグネシゥムの影響*}

\section{一 A1-Si 合金鋳物の衝撃強さに関する検討（第 4 報）}

\section{小松 登**・中村 元志** • 山本 善章** • 山本 修之**}

Effects of $\mathrm{Mg}$ on the impact strength of $\mathrm{Al}-\mathrm{Si}-\mathrm{Cu}$ alloys*

-Observations of impact strength of Al-Si alloys (4th report)-

UDC $669.715^{\prime} 782^{\prime} 5-14: 620.178 .7$

\author{
KOMATSU Noboru**, NAKAMURA Motoyuki**, \\ YAMAMOTO Yoshiaki** and YAMAMOTO Nobuyuki**
}

Effects of addition of $\mathrm{Mg}(0.1 \sim 1.2 \mathrm{wt} \%)$ to $\mathrm{Al}-\mathrm{Si}-\mathrm{Cu}$ alloys on the impact strength and structures were examined by means of Charpy impact test and metallographic method.

The following four types of specimens were used for the experiments.

(a) As cast.

(b) Solution treated at $500^{\circ} \mathrm{C}$ for $240 \mathrm{~min}$.

(c) Age hardened at $160^{\circ} \mathrm{C}$ for $300 \mathrm{~min}$. after solution treatment.

(d) Age hardened at $200^{\circ} \mathrm{C}$ for $300 \mathrm{~min}$. after casting.

The results obtained were as follows:

(1) The impact strength of $\mathrm{Al}-\mathrm{Si}-\mathrm{Cu}$ alloys containing $\mathrm{Mg}$ was much increased by solution treatment at $500^{\circ} \mathrm{C}$ for $240 \mathrm{~min}$. as observed in $\mathrm{Al}-\mathrm{Si}$ and $\mathrm{Al}-\mathrm{Si}-\mathrm{Cu}$ alloys. The behavior of impact rupture was characterized by a great increase in time for formation and propagation of cracks with a small increase in maximum load, which resulted in a great increase in impulse. The above behavior would be attributed to the dissolution of $\mathrm{Cu}$ and $\mathrm{Si}$ into matrix and the changes in shape and amount of crystallites.

(2) The impact strength of as cast and solution treated alloys were likely to be decreased with the increase in $\mathrm{Mg}$ content. The behavior of impact rupture was characterized by a decrease in time for formation and propagation of cracks with a constant maximum load. The above behavior would be attributed to the increase in remaining undissolved crystallites due to the addition of $\mathrm{Mg}$.

(3) The impact strength of the alloys age hardened at $160^{\circ} \mathrm{C}$ for $300 \mathrm{~min}$. after solution treatment and those age hardened at $200^{\circ} \mathrm{C}$ for $300 \mathrm{~min}$. after casting were likely to be decreased with the increase in $\mathrm{Mg}$ content.

The above behavior of impact rupture was characterized by the decrease in time for formation and propagation of cracks with the increase in maximum load, which led to the decrease in impulse. The behavior of the former alloys would be attributed to the composite effect of changes in both of shape and amount of crystallites (as described in (1)) and age hardening. Therefore, the increase in maximum load would be attributed to the effect of age hardening.

(4) It was found that the hardness of $\mathrm{Al}-\mathrm{Si}-\mathrm{Cu}-\mathrm{Mg}$ alloys after ageing was not different between the specimen age hardened at $200^{\circ} \mathrm{C}$ for $300 \mathrm{~min}$. after casting and that age hardened at $160^{\circ} \mathrm{C}$ for $300 \mathrm{~min}$. after solution treatment, but the impact strength was much different between the both. It was observed by fractography that the former specimen showed brittle fracture and the latter showed ductile fracture, though they had the same composition and hardness.

(Received June 5, 1970)

* 軽金属学会第37回秋期大会 $(44-11-12)$ にて発表した。

** 株式会社豊田中央研究所 (名古屋市) TOYOTA Central Research and Development Labs., Inc. (Nagoya) 


\section{1. まえがき}

$\mathrm{Al}-\mathrm{Si}-\mathrm{Cu}$ 系合金の衝撃值 は時効硬度上昇に反比例し て減少するというような単純な変化のみでなく，晶出物 の量および形状などによつても大きく変化することを前 報1で明らかにした。

$\mathrm{Al}-\mathrm{Si}-\mathrm{Cu}$ 系合金にマグネシウムを添加すると時効硬 度は上昇するが，著しく脆性を增すといわれている22 5) この場合も $\mathrm{Al}-\mathrm{Si}-\mathrm{Cu}$ 系と同様にかたさの上䒜に反比例 して衝撃値が下がる(6)7というだけでなく，晶出物など組 織構成成分の形状または量が大きく寄与することが考え られるが，両者を区別した形で衝撃值変化を検討した報 告は少ない上うに思われる。したがつて本研究は初晶け い素の晶出しない範囲の $\mathrm{Al}-\mathrm{Si}-\mathrm{Cu}$ 合金にマグネシウム を添加し，加熱処理を施し，組織構成成分形状を変化ま たは時効素を出現せしめこれらと衝撃強さとの関連を知 ろうとして実施した。

\section{2. 試料および実験方法}

溶解，加熱処理，衝撃試験などの実験方法は，すべて 前報8) と同様にして行なつてある。すなわち，試料は， $\mathrm{Al}-6 \% \mathrm{Si}-3.6 \% \mathrm{Cu}, \mathrm{Al}-4.5 \% \mathrm{Cu}, \mathrm{Al}-12 \% \mathrm{Si}$ 合金を用い， それらにマグネシウムを $\mathrm{Al}-10 \% \mathrm{Mg}$ 合金の形で添加し けい素 $6 \%$ ，銅 4.5\%，マグネシウム 0〜1.0\% となる ように配合した。それらを杖黒鉛るつぼを用いシリコニ ット炉で $750^{\circ} \mathrm{C}$ に加熱溶解し同温度に 10 分間保持後真空 加熱炉に移し同温度で 30 分間 $0.20 \mathrm{mmHg}$ 真空中で脱ガ 又処理を行ない $670^{\circ} \mathrm{C}$ に冷却後 $300^{\circ} \mathrm{C}$ に予熱した肉厚 $20 \mathrm{~mm}$ の10 $\times 180$ の金型に鋳造した。

鋳造後約 30 秒間, 同金型に保持後，鋳造材を $25^{\circ} \mathrm{C}$ の水 中で急冷した。それを $55 \times 10 \square$ に切断し $2 \phi$ の穴をあ

Table 1 Chemical compositions of $\mathrm{Al}-\mathrm{Si}-\mathrm{Cu}-\mathrm{Mg}$ alloys, analyzed by fluorescent $\mathrm{X}$-ray technique and emission spectrochemical analysis.

\begin{tabular}{c|c|c}
\hline Si (\%) & $\mathrm{Cu}(\%)$ & $\mathrm{Mg}(\%)$ \\
\hline \multirow{2}{*}{6.1} & 4.6 & 0.01 \\
& 4.5 & 0.09 \\
& 4.7 & 0.24 \\
& 4.7 & 0.33 \\
& 4.3 & 0.39 \\
& 4.7 & 0.51 \\
& 4.5 & 0.57 \\
& 4.8 & 0.73 \\
& 3.9 & 1.20 \\
\hline
\end{tabular}

け衝撃試験片とし，所定の熱処理を施した後，室温で衝 撃試験を行なつた。用いた熱処理はつぎの通りである。

鋳放し材：鋳造後, 金型中に 30 秒保持後 $25^{\circ} \mathrm{C}$ の水中で 急冷処理したもの。

$\mathrm{T} 4$ 材： $500^{\circ} \mathrm{C}$ で 4 時間加熱後，水焼入れ処理

T5 材：鋳放し材を鋳造後 1 時間以内に $200^{\circ} \mathrm{C}$ で 5 時間加熱後, 空冷処理

$\mathrm{T} 6$ 材: $500^{\circ} \mathrm{C}$ で 4 時間加熱後, 水燒入れし直ちに $160^{\circ} \mathrm{C}$ で 5 時間加熱後空冷処理

衝撃試験，かたさ測定は室温時効による影響をさける ため, 鋳放し材は鋳造後 1 時間以内，その他は処理後 5 分以内に䘕なた。衝撃試験は $5 \mathrm{~kg}-\mathrm{m}$ のシャルピー衝 撃試験機を用い,衝撃面は $2 \phi$ の穴をあけた面である。 かたさはガリレオ硬度計でロックウエルBスケールで測 定した。

用いた試験片の化学成分を Table 1 に示す。

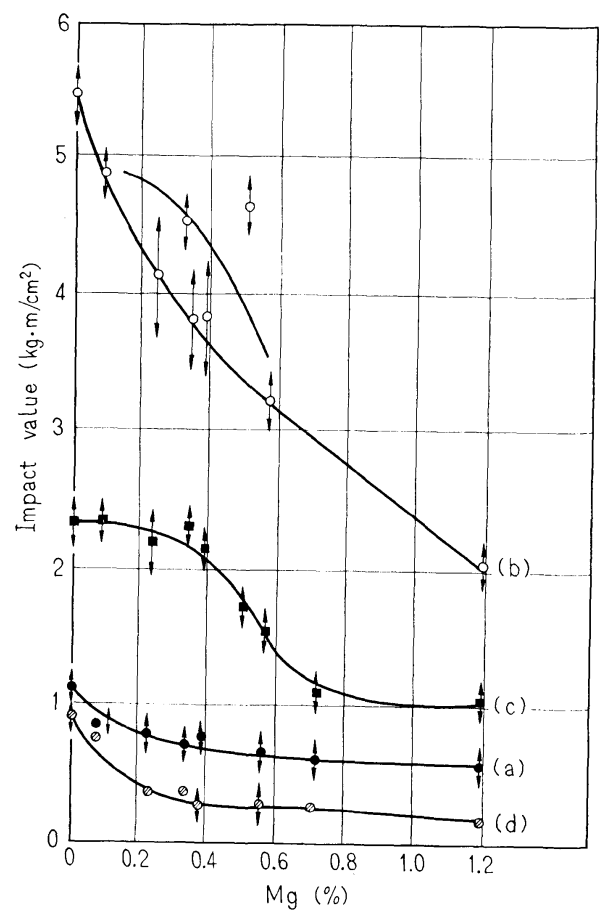

Fig. 1 Impact value of $\mathrm{Al}-6.1 \% \mathrm{Si}-4.5 \% \mathrm{Cu}$ alloys as a function of $\mathrm{Mg}$ content.

(a) As cast

(b) Solution treated at $500^{\circ} \mathrm{C}$ for $240 \mathrm{~min}$.

(c) Age hardened at $160^{\circ} \mathrm{C}$ for $300 \mathrm{~min}$. after solution treatment

(d) Age hardened at $200^{\circ} \mathrm{C}$ for $300 \mathrm{~min}$. after casting 


\section{3. 実験結果ならびに考察}

$\mathrm{Al}-6.1 \% \mathrm{Si}-4.5 \% \mathrm{Cu}$ 合金にマグネシウムを $0.1 \sim 1.2$ \%添加した各処理材の衝撃值とかたさの変化を Fig.1 お よびFig. 2 に示した。Fig. 1 から衝撃値はT4材>T6材 >鋳放し材 > T5 材の順ですべてマグネシウム添加 量の 増加と共に低下した。

鋳放し材の場合，マグネシウム添加量によるかたさの 変化は見られなかつたが衝撃值はマグネシウム添加量, $0.5 \%$ まで低下し, それ以上マグネシウムを添加しても 変らなかつた。

T4 処理材ではかたさはマグネシウム量にあまり関係 なく鋳放し材よりやや高いかたさで一定であつたが，衝 撃值はマグネシウム添加量と共に減少し $0.5 \%$ マグネシ ウムまでの範囲でバラツキが著しく大きかつた。衝撃值 は鋳放し材の 4 倍以上と向上し，その程度はマグネシウ ム量の少ないほど顕著であつた。

$\mathrm{T} 6$ 処理材ではかたさはマグネシウム $0.1 \%$ で $\mathrm{H}_{\mathrm{R}} \mathrm{B} 68$ と ほぼ最高值となり，そ出以上マグネシウムを添加しても あまり変化しなかつたが, 衝撃值はマグネシウム $0.4 \%$ まで一定で，それ以上マグネシウムを添加する上著しく 減少した。

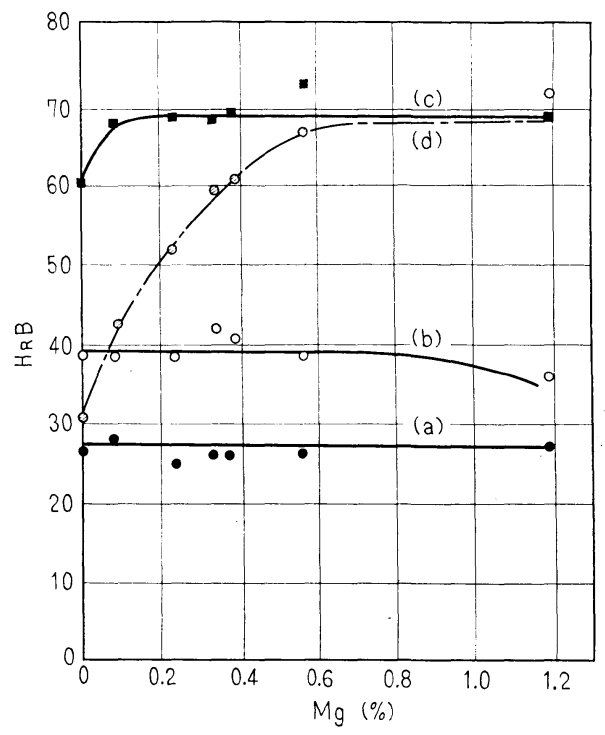

Fig. 2 Hardness of $\mathrm{Al}-6.1 \% \mathrm{Si}-4.5 \% \mathrm{Cu}$ alloys as a function of $\mathrm{Mg}$ content.
(a) As cast
(b) Solution treated at $500^{\circ} \mathrm{C}$ for $240 \mathrm{~min}$.
(c) Age hardened at $160^{\circ} \mathrm{C}$ for $300 \mathrm{~min}$. after solution treatment
(d) Age hardened at $200^{\circ} \mathrm{C}$ for $300 \mathrm{~min}$. after casting

T5処理材ではかたさは鋳造焼入れ処理 ${ }^{9)}$ の効果もあつ

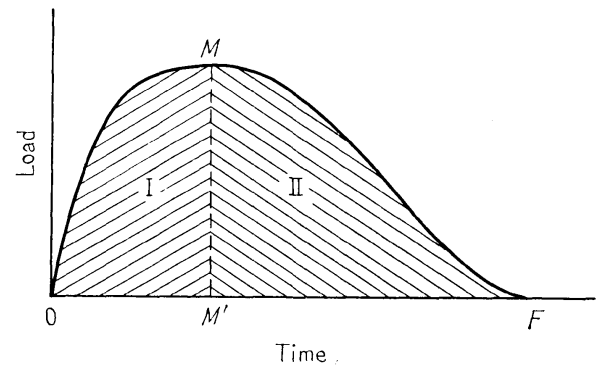

Fig. 3 Shematic representation of relation between load and time in Charpy impact test.

M: Maximum load

I: Crack initiation impulse

II : Crack propagation impulse

$\mathrm{OM}^{\prime}$ : Crack initiation time

$\mathrm{M}^{\prime} \mathrm{F}$ : Crack propagation time
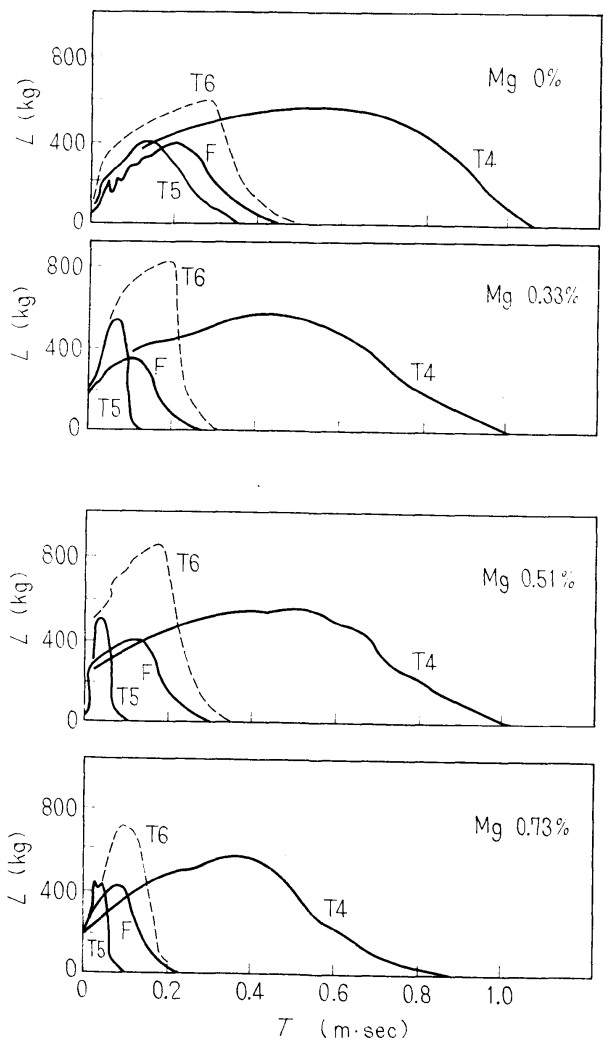

Fig. 4 Load-time curves for test pieces of Al-6.1 $\% \mathrm{Si}-4.5 \% \mathrm{Cu}-\mathrm{Mg}$ alloys.

F : As cast

$\mathrm{T} 4$ : Solution treated at $500^{\circ} \mathrm{C}$ for $240 \mathrm{~min}$.

T6: Age hardened at $160^{\circ} \mathrm{C}$ for $300 \mathrm{~min}$. after solution treatment

T5: Age hardened at $200^{\circ} \mathrm{C}$ after casting 
てマグネシウム $0.6 \%$ までその添加量と共に上昇し T6処 理材の最高かたさとほぼ同じとなりマグネシウム $0.6 \%$ 以上で一定を示した。衝撃值はマグネシウム $0.3 \%$ まで 低下し鋳放し材に比べてさらに低くなり，それ以後一定 の値を示した。

このようにマグネシウム添加量に対するかたさの変化 と衝撃值の変化との間には必ずしも関係は認められない。

そこで Fig. 1 で比較的衝撃値の大きい変化を示した マグネシウム添加量 $0,0.33,0.51,0.73 \%$ の試料につい て前出の各処理を行ない衝撃破断時の荷重一時間線図の 測定を行なつた。測定線図の形状を定性的に書くと Fig. 3 に示すようで最大荷重, クラック形成力積, クラック 伝播力積, クラック形成時間, クラック伝播時間を図中

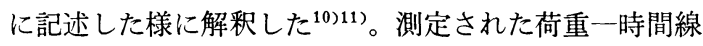
図をマグネシウム添加量, 処理条件について示すと Fig. 4 のようである。

Fig. 4 から Al-Si-Cu-Mg 系合金いずれも Al-Si-Cu 系合金と同じ傾向1"示していることがわかる。すなわ ち鋳放し材に比べ $\mathrm{T} 4$ 処理材では最大荷重が上昇，クラ ック形成, 伝播力積の増加, クラック形成, 伝播時間が 長くなり吸収エネルギー量が増加して衝撃值が高くなつ ている。

$\mathrm{T} 6$ 処理材では $\mathrm{T} 4$ 処理材に比べ最大荷重は増加してい るが，クラック形成，伝播力積が減少そしてクラック形

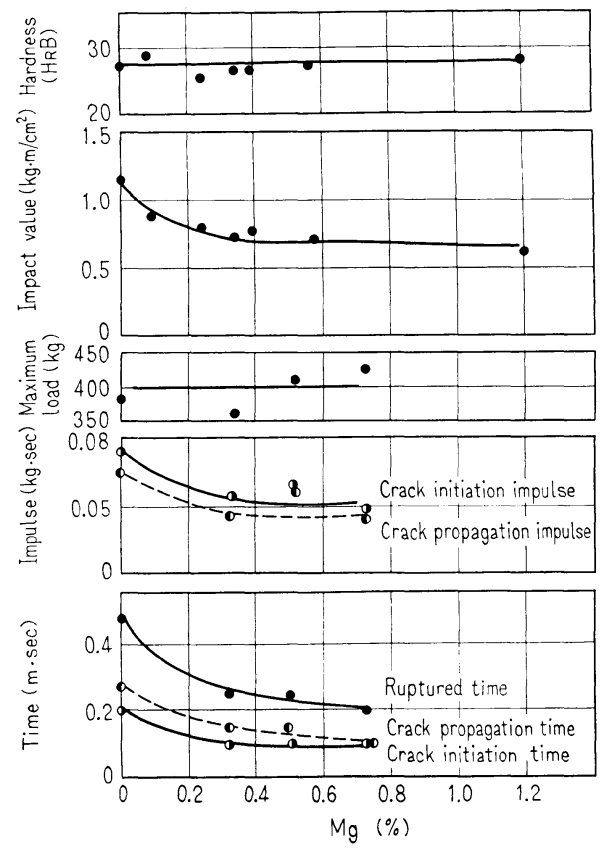

Fig. 5 Charpy impact properties of $\mathrm{Al}-6.1 \% \mathrm{Si}-$ $4.5 \% \mathrm{Cu}$ alloys, as cast, as a function of $\mathrm{Mg}$ content.
成，伝播時間が鋳放し材とほぼ同じ位に減少し吸収エネ ルギー量が減少して衝撃值が低下している。

$\mathrm{T} 5$ 処理材の衝撃強さは鋳放し材に比べ最大荷重が増 加しているが, クラック形成, 伝播力積が減少, クラッ ク形成, 伝播時間が減少し吸収エネルギー量が減少して 衝撃値は鋳放し材より低い值を示している。

鋳放し材に比較して $\mathrm{T} 4$ 処理材の最大荷重の 増加はか たさの増加から， $\alpha$-アルミニウム地一の銅の固溶による

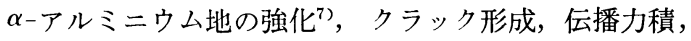
クラック形成，伝播時間の増加は Photo. 1 に示すよう に晶出共晶けい素の針状から球状への変化 ${ }^{12}$ および晶出 物量の減少に依存したものと考えられる。

T4処理材に比較して $\mathrm{T} 6$ 処理材, 鋳放し材に比較して の $\mathrm{T} 5$ 処理材の最大荷重の増加およびクラック形成, 伝 播力積, クラック形成, 伝播時間の減少は, 共に光学顕 微鏡組織的には晶出組織形状に差が認められないがかた さの上昇から時効素の析出によるものと考えられる。

鋳放し材についてマグネシウム添加量とかたさ，衝撃 值, 荷重一時間線図からえられた最大荷重, クラック形 成および伝播力積, クラック形成および伝播時間の関係 を，Fig. 5 にまとめて示した。Fig. 5 からマグネシウム 添加量増加にともなう衝撃值の低下はクラック 形成力 積, クラック伝播力積の低下に帰因することがわかる。 そして, そのとおりの最大荷重は変化しなかつた。破断 時間はマグネシウム添加量の増加と共にクラック形成,

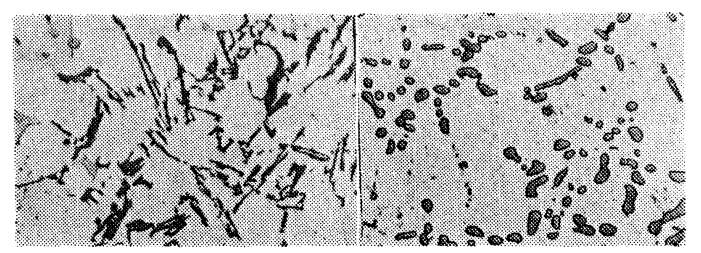

(a )

(b)

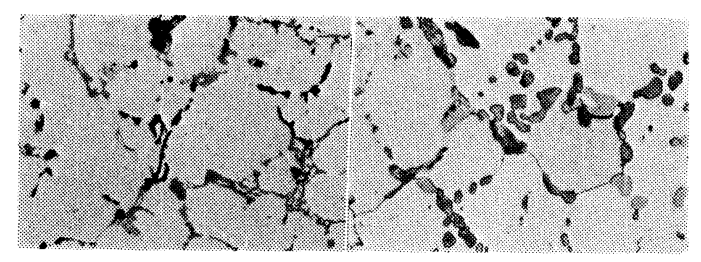

(c)

(d)

Photo. 1 Microstructures of $\mathrm{Al}-6.1 \% \mathrm{Si}-4.5 \% \mathrm{Cu}$ alloys containing $\mathrm{Mg}$, etched. $(\times 400)$

(a) $0.22 \% \mathrm{Mg}$, as cast

(b) $0.22 \% \mathrm{Mg}$, solution treated at $500^{\circ} \mathrm{C}$ for 300 $\min$.

(c) $1.20 \% \mathrm{Mg}$, as cast

(d) $1.20 \% \mathrm{Mg}$, solution treated at $500^{\circ} \mathrm{C}$ for 300 min. 
伝播時間両方の減少により低下した。したがつて鋳放し 材は，マグネシウムが添加されると衝撃破断に対してク ラックが形成され易く，そのクラックが伝播し易い状態 になることがわかる。Fig. 6 はマグネシウム添加量と鋳 放し材中のけい素，銅，マグネシウムの分布量との関係 を示しているが，本実験方法のような鋳造方法の場合， マトリックス中ではけい素, 銅量は変化なくマグネシウ ム量のみがマグネシウム添加量と共に増加していること がわかる。0.34\%マグネシウムでマグネシウム化合物の 晶出も認められる。しかしこの変化に対しかたさも最大 荷重も変化していないことからマトリックス中のマグネ

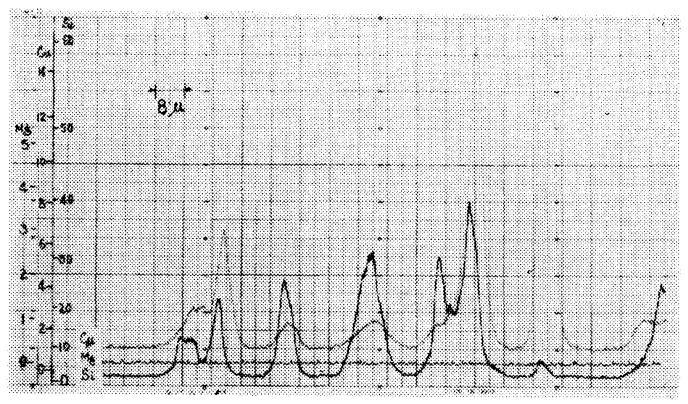

(a) $0 \% \mathrm{Mg}$

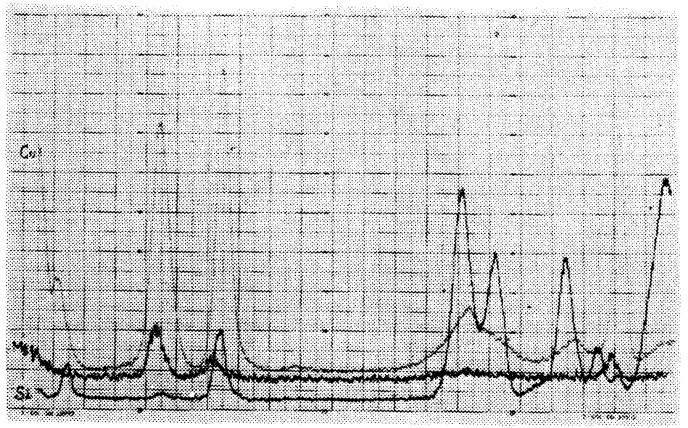

(b) $0.34 \% \mathrm{Mg}$

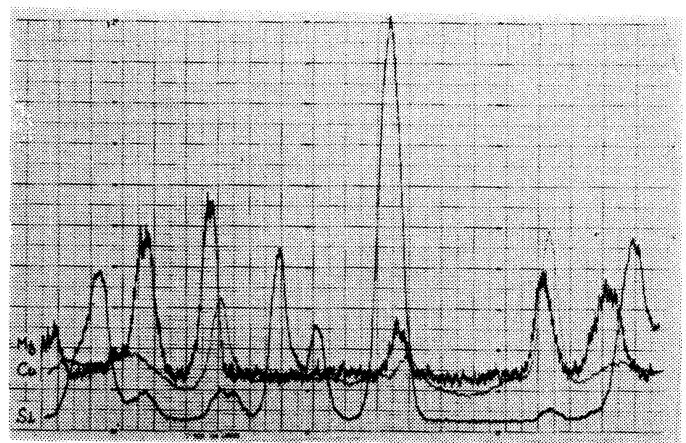

(c) $0.72 \% \mathrm{Mg}$

Fig. 6 Electron probe micro-analysis charts obtained from $\mathrm{Al}-6.1 \% \mathrm{Si}-4.5 \% \mathrm{Cu}-\mathrm{Mg}$ alloys, as cast.
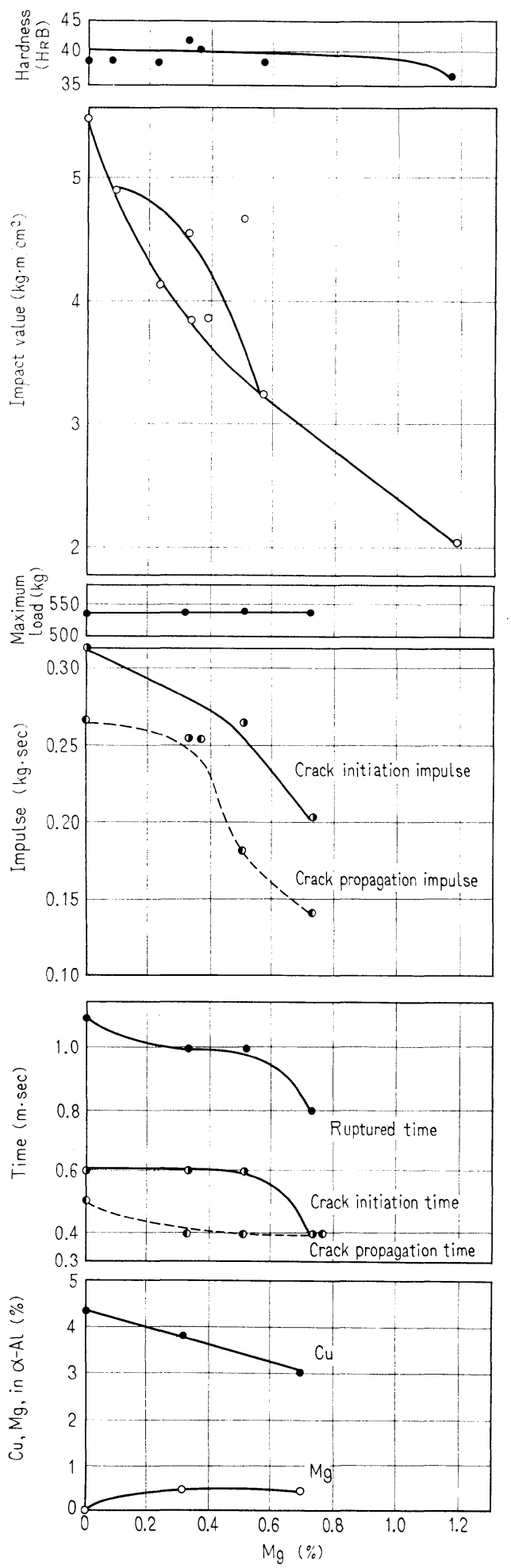

Fig. 7 Charpy impact properties of $\mathrm{Al}-6.1 \% \mathrm{Si}-$ $4.5 \% \mathrm{Cu}$ alloys, solution treated at $500^{\circ} \mathrm{C}$ for $240 \mathrm{~min}$, as a function of $\mathrm{Mg}$ content. 
シウム量の増加は，これらと関係が薄いと思われる。

Fig. 7 に示すように鋳放し材を $\mathrm{T} 4$ 処理すると衝撃值 は鋳放し材に比べ著しく大きくなるが，マグネシウム添 加量の増加と共に急激な減少を示した。一方, 荷重一時 間線図から衝撃值の減少はクラック形成，伝播力積の 0.5\% マグネシウムまでのわずかの減少，それ以後の急 激な減少に依存するが，その抢りの最大荷重值はマグネ シウム添加量が増加してもほとんど変わらず一定値を示 した。衝撃破断時間はマグネシウム添加量の増加と共に やや減少の傾向を示したがクラック形成時間は，0.51\% マグネシウムまでほぼ一定でクラック伝播時間はマグネ

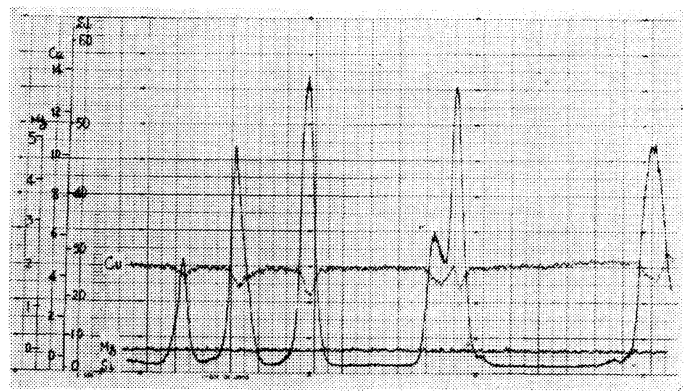

(a) $0 \% \mathrm{Mg}$

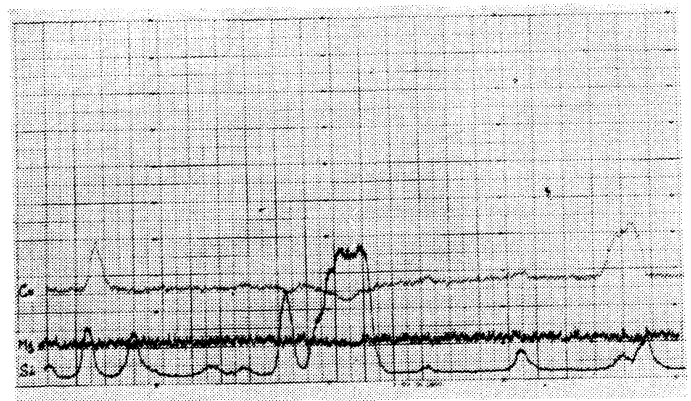

(b) $\quad 0.34 \% \mathrm{Mg}$

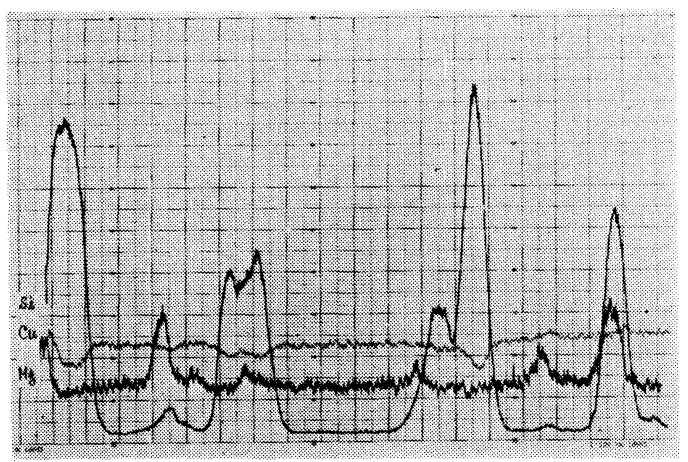

(c) $\quad 0.72 \% \mathrm{Mg}$

Fig. 8 Electron probe micro-analysis charts obtained from $\mathrm{Al}-6.1 \% \mathrm{Si}-4.5 \% \mathrm{Cu}-\mathrm{Mg}$ alloys, solution treated at $500^{\circ} \mathrm{C}$ for $240 \mathrm{~min}$.
シウム添加で減少した。したがつて T4 処理材はマグネ シウムが添加されると衝撃破断に対して $0.5 \%$ マグネシ ウムまでは破断時間に差を生ぜず，クラック形成力積， 伝播力積が減少する。 $0.5 \%$ マグネシウム以上は破断時 間も減少しクラックが形成され易く伝播し易い状態とな ることがわかる。Fig 8 はマグネシウム添加量と T4 処 理材中のけい素，銅，マグネシウムの分布量との関係を 示しているが，マグネシウム添加量の増加と共に Fig. 7 に示すように $\alpha-$ アルミニウム中への銅の固溶量が少な くなりマグネシウム固溶量が増加している。ことがわかる したがつてマグネシウム添加量の増加につれて Photo. 1 にも示寸ように $\mathrm{T} 4$ 処理後の残存銅化合物相およびマ グネシウム化合物相の増加することがわかる。かように
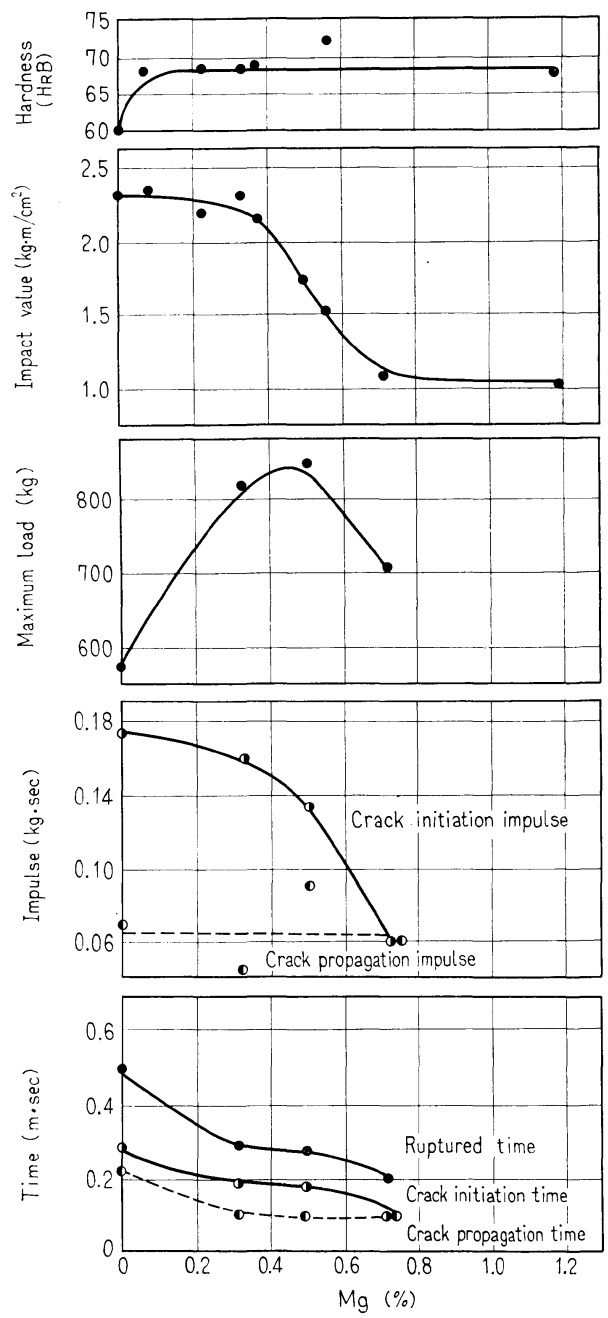

Fig. 9 Charpy impact properties of $\mathrm{Al}-6.1 \% \mathrm{Si}-4.5$ $\% \mathrm{Cu}$ alloys, age hardened at $160^{\circ} \mathrm{C}$ for $300 \mathrm{~min}$. after solution treatment, as a function of $\mathrm{Mg}$ content. 


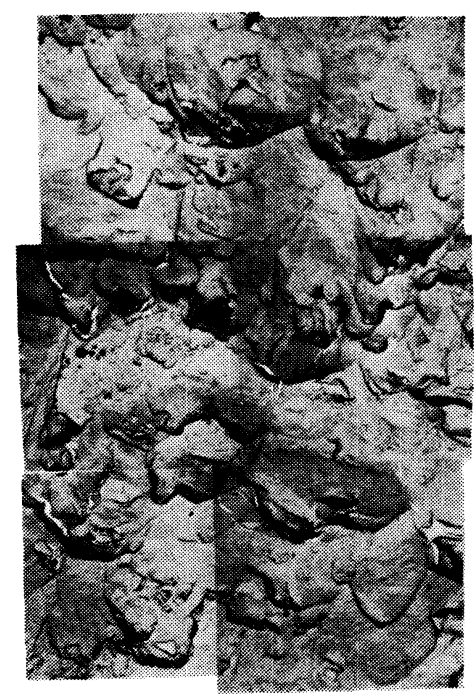

( b )

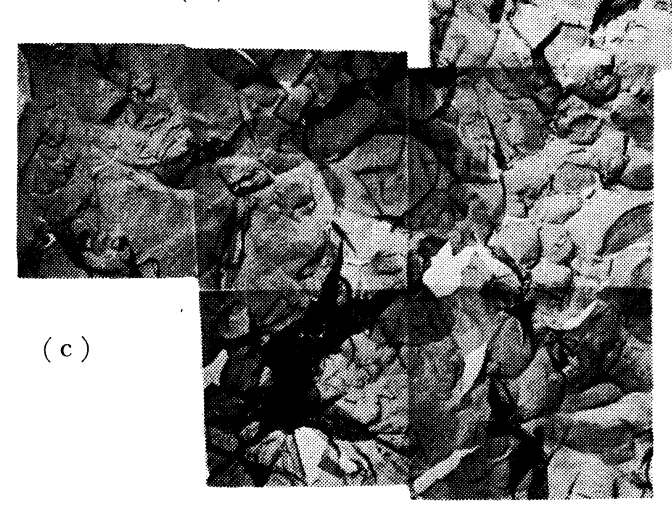

Photo. 2 Micro fractographs of Al-6.1\% $\mathrm{Si}-3.5 \%$ $\mathrm{Cu}-0.34 \% \mathrm{Mg}$ after impact test.
(a) Age hardened at $200^{\circ} \mathrm{C}$ for $300 \mathrm{~min}$. after casting
(b) Solution treated at $500^{\circ} \mathrm{C}$ for $240 \mathrm{~min}$.
(c) Age hardened at $160^{\circ} \mathrm{C}$ for $300 \mathrm{~min}$. after solution treatment

$\mathrm{Al}-\mathrm{Si}-\mathrm{Cu}$ 合金へのマグネシウム 添加量による衝撃值の 低下は，未固溶の残存晶出物量の増加も一因となつてい ると考えられる。

Fig. 9 に示すように溶体化処理後ただちに焼戻し処理 した T6 処理材は，T4 処理材よりかたさが増加し衝撃破 断時の最大荷重はマグネシウム添加量 $0.5 \%$ まで増加し 以後減少した。クラック形成力積はマグネシウム添加量 $0.3 \%$ を゙ほぼ一定, 以後急激し, クラック伝播力積はマ グネシウムの有無によらず一定であつた。衝撃破断時間

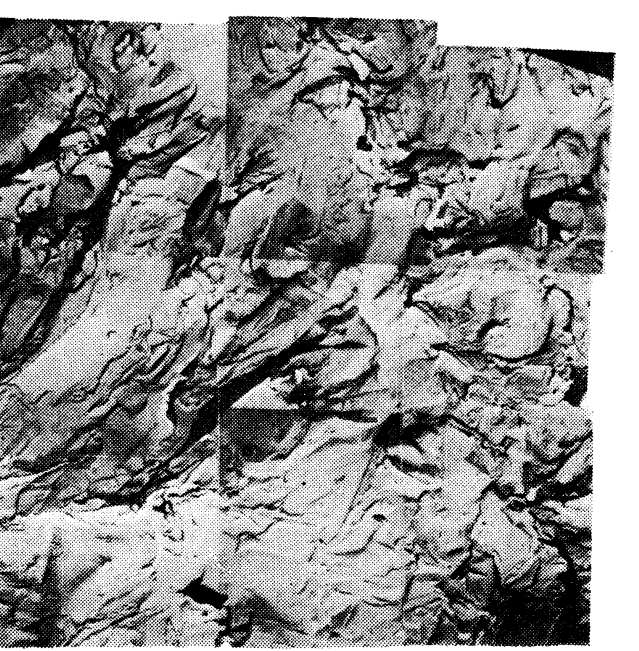

(a)

$15 \mu$

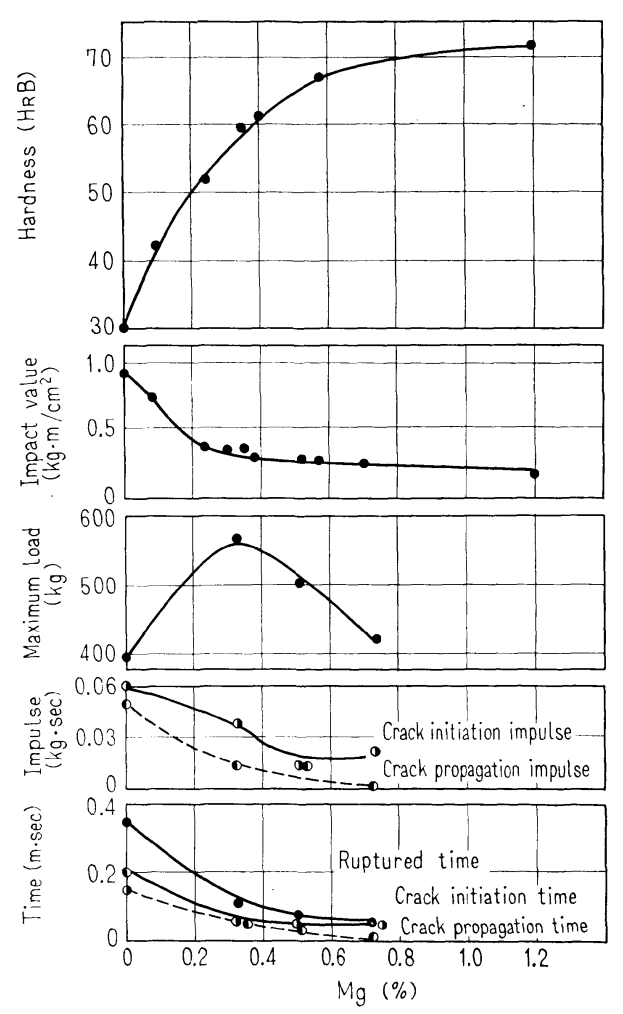

Fig. 10 Charpy impact properties of Al-6.1\% $\mathrm{Si}-4.5 \% \mathrm{Cu}$ alloys, age hardened at $200^{\circ} \mathrm{C}$ for $300 \mathrm{~min}$. after casting, as a function of $\mathrm{Mg}$ content. 
はクラック形成,伝播時間ともにマグネシウム約 $0.3 \%$ で減少し, 以後変わらず, クラック形成時間のみはマグ ネシウム $0.5 \%$ 以上で再び減少した。これより，マグネ シウ $40.4 \%$ までの衝撃值がほぼ一定であることは，ク ラック形成および伝播力積が一定であることに帰因する が，これはクラック形成，伝播時間が共に減少している ことから最大荷重の増加により見かけ上ほぼ一定を示し ておりマグネシウムの添加は衝撃值が一定であつても衝 撃破断時間が短かくなつていることからクラックの形成 および伝播時間を早めることになる。マグネシウム 0.4 \%以上の衝撃值の減少はクラック形成力積の減少による が最大荷重, クラック形成時間も滅少していることから $0.4 \%$ 以上のマグネシウムの添加は材質にクラックを形 成させ易く脆、状態にすることがわかる。T6処理材の晶 出物形状は T4 処理材のそれとほぼ等しいと考えられる から, $\mathrm{T} 6$ 処理材と $\mathrm{T} 4$ 処理材の衝撃値の差は時効効果に 伴うものであると考えられるが，この場合，時効による かたさ増加に伴つて衝撃値は変化せず，時効かたさが飽 和して衝撃值が低下しているといえる。

なお，マグネシウム添加量0.4\%の T6 処理材はFig. 8 に示した $\mathrm{T} 4$ 処理材での $\alpha-$ アルミニウム地でのマグネ シウム量が飽和寸る点に相当し興味がある。

T5 処理材の衝撃強さは Fig. 10 に示すよらにかたさ の増加に対して減少している。この場合最大荷重はマグ ネシウム添加量 $0.33 \%$ で最高値を, それ以上のマグネシ ウム添加量の増加は最大荷重を減少させる。クラック形 成, クラック伝播力積はマグネシウム $0.33 \%$ まで減少, 以後ほぼ一定であつた。破断時間はクラック形成，伝 播時間共にマグネシウム $0.3 \%$ まて減少, 以後クラッ ク形成時間はほぼ一定, クラック伝播時間はゆるやかに 減少した。したがつてマグネシウム $0.3 \%$ までの衝撃強 さの減少はクラック形成およびクラック伝播力積の減少 とほぼ比例し，破断時間の減少からマグネシウムの添加 はクラックを形成し易く伝播し易くなつているといえ る。T5 処理材は晶出物形状は鋳放し材とほぼ変らず, その上に時効処理による効果が加わつていることから

Fig. 1 からもわかる様に鋳放し材よりさらに脆くなつ ているといえる。

これをさらに確かめるためにマグネシウム添加量 $0.3 \%$ 合金の衝撃值 $0.25 \mathrm{~kg}-\mathrm{m} / \mathrm{cm}^{2}$ をもつ T5 処理材の衝撃破 断後の破面観察を二段レプリカ法により行ない検討して

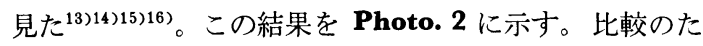
めに衝撃值 $4.5 \mathrm{~kg}-\mathrm{m} / \mathrm{cm}^{2}$ の $\mathrm{T} 4$ 処理材掞よび $2.2 \mathrm{~kg}$ $\mathrm{m} / \mathrm{cm}^{2}$ の $\mathrm{T} 6$ 処理材も示した。Photo. 2 (a) から T5 処 理材はいわゆる勒性を示すDimpleパターンは見られず， へき開状および粒界破壊を示すパターンが見られ脆い破 面を呈した。一方 Photo. 2(b) に示す T4 処理材は荷重
方向とほぼ平行に $10 \sim 20 \mu$ の長く伸びた Dimple パター ンが多く見られ勒性破面を呈した。また Photo. 2 (c) に 示す $\mathrm{T} 6$ 処理材は荷重方向と平行に $\mathrm{T} 4$ 処理材と同様な Dimple パターンが多く見られたが，その大きさは 5〜 $10 \mu$ であつた。なお $\mathrm{T} 4$ 処理材に比べて $\mathrm{T} 6$ 処理材のパ ターンの大きさが小さいことは興味ある現象であつた。

\section{4. ま と め}

$\mathrm{Al}-\mathrm{Si}-\mathrm{Cu}$ 合金に 0.1 1.2\% マグネシウムを添加し, $\mathrm{T} 4, \mathrm{~T} 5, \mathrm{~T} 6$ の加熱処理後, 衝撃強さを検討した結果つぎ のことがわかつた。

(1) T4 処理により晶出物形状を変化させると各マグ ネシウム添加合金とも衝撃值が大きくなり，いずれも最 大荷重值がやや増加すると共にクラック形成および伝播 の力積および時間が著しく増加するといら形式の破断を 示す。これは $\mathrm{Al}-\mathrm{Si}$ 二元合金, $\mathrm{Al}-\mathrm{Si}-\mathrm{Cu}$ 三元合金と全く 同じ傾向である。これらはマトリックス中への銅または けい素の溶入および晶出物形状, 量の変化にともなうも のと考えられる。

（2）鋳放し材と $\mathrm{T} 4$ 処理材はマグネシウム添加量の増 加につれて衝撃值が減少したが，いずれも最大荷重值は 変化せず，クラック形成および伝播の力積および時間が 減少するという形式で破断した。これはいずれもマグネ シウム添加による晶出物量または未固溶残存晶出物量の 増加による影響が大きいと考えられる。

(3) T5 処理材および T6 処理材はマグネシウム添加 量の増加につれてやはり衝撃值を減少させる傾向を示す が，これらは最大荷重値を増加させ，クラック形成およ び伝播の力積および時間を減少するという形式の破断を 示す。 $\mathrm{T} 6$ 処理材のこの変化は(1)および時効効果の複合 効果を示しているが，最大荷重值の増加はこの種合金の 時効硬化に伴うものと考えられる。

(4) したがつて $\mathrm{Al}-\mathrm{Si}-\mathrm{Cu}-\mathrm{Mg}$ 系合金では $\mathrm{T} 5$ 処理材 と $\mathrm{T} 6$ 处理材では時効かたさが同じであつても衝撃值が 著しく異なり，同組成，同かたさで T5 処理材が脆性破 面を示す場合に T6 処理材が延性破面を示すような例が 現われる。

\section{参 考 文 献}

1) 小松, 中村, 山本; 軽金属 20 (1970) 7

2) Eberhard Schürmann; Giesserei 56 (1969) 4. 77

3) Robert C. Lemon; SAE paper 670465 (1967) 1

4) F. A. Badia; SAE paper 680267 (1968) 1

5) S. F. Frederick, W. A. Bailey; Trans Metal Soc. AIME 242 (1968) 2063 
6) Harris, R. C., S. Lipson, H. Rosenthal; AFS Trans 64 (1956) 470

7) I.D. Olliff, V. Kondic; AFS Cast Metals R.J. 5 (1969) 1, 25

8) 小松, 中村, 山本 ; 軽金属 19 (1969）9, 398

9) 小松, 中村, 大林, 本多; 軽金属第 38 回講演概 要 19 (1970)

10）田中，布村；日金学誌 27 (1963）9, 439

11）田中，梅川；日金学誌 27 (1963) 11, 535
12）小松，中村，山本 ; 軽金属 19 （1969）10, 445

13) C. D. Beachem; Trans ASM 56 (1963) 318

14) A. Kasak, V. K. Chandhok, E. J. Dulis; Trans ASM 56 (1963) 455

15) A. Phillips; Electron Fractozraphy Hand Book AD612912 (1965)

16) G. Henry, J. Plateau; LA Microfractographie II $3.2-17$ (1967) 